\title{
Suspension High Velocity Oxy-Fuel (SHVOF) Spray of Delta-Theta Alumina Suspension: Phase Transformation and Tribology
}

\author{
T. A. Owoseni ${ }^{1}$, J. W. Murray ${ }^{1}$, Z. Pala ${ }^{2}$, E. H. Lester ${ }^{1}$, D. M. Grant ${ }^{1}$, T. Hussain ${ }^{1 *}$ \\ ${ }^{1}$ Faculty of Engineering, University of Nottingham, Nottingham, NG7 2RD, UK \\ ${ }^{2}$ GE Aviation, Beranovych 65, Prague, Czech Republic
}

Corresponding author: +44 (0) 115951 3795; tanvir.hussain@nottingham.ac.uk

\begin{abstract}
Suspension high-velocity oxy-fuel (SHVOF) thermal spray is an emerging spray technology that enables the processing of nanometric feedstock. Although SHVOF thermal sprayed alumina coatings prepared from alpha alumina feedstock have been widely reported, a metastable $\delta-\theta \mathrm{Al}_{2} \mathrm{O}_{3}$ feedstock has yet to be investigated despite its low cost and commercial availability. In this study, an aqueous $\delta-\theta \mathrm{Al}_{2} \mathrm{O}_{3}$ suspension was sprayed on to a stainless steel
\end{abstract} (SS 304) substrate via SHVOF thermal spraying using an internal injection UTP TopGun. Xray diffraction (XRD) of the as-sprayed coating showed $\delta-\theta \mathrm{Al}_{2} \mathrm{O}_{3}$ to $\gamma-\mathrm{Al}_{2} \mathrm{O}_{3}$ transformation upon spraying, along with amorphous/nanocrystalline phase formation. Furthermore, postspray heat treatment of the coatings was performed at $600-750{ }^{\circ} \mathrm{C}$ for 6 and $48 \mathrm{~h}$. The microhardness and indentation fracture toughness of the heat treated coatings increased by a factor of two compared to the as-sprayed coatings: due to grain refinement, pore consolidation and phase transformation of amorphous and $\gamma-\mathrm{Al}_{2} \mathrm{O}_{3}$ to $\delta-\mathrm{Al}_{2} \mathrm{O}_{3}$. Unlubricated sliding wear tests were conducted at room temperature $\left(\sim 25^{\circ} \mathrm{C}\right.$, relative humidity $\left.\sim 60 \%\right)$ using $\alpha-\mathrm{Al}_{2} \mathrm{O}_{3}$ balls $(\varnothing 9.5 \mathrm{~mm})$ as the counter body at a normal load of $16.8 \mathrm{~N}$ to study the wear performance of the coatings. The wear rate of the as-sprayed coating and the coating heat treated at $600{ }^{\circ} \mathrm{C}$ for $6 \mathrm{~h}$ is of the order of $10^{-9} \mathrm{~mm}^{3}(\mathrm{Nm})^{-1}$, a noticeable improvement over conventional alumina coatings. The coatings heat treated at $750{ }^{\circ} \mathrm{C}$ for both 6 and $48 \mathrm{~h}$ failed abruptly by severe wear due to their pre-cracked surface. 
Keywords: SHVOF; suspension thermal spray; alumina phase evolution; delta-theta alumina; sliding wear; Rietveld refinement

\section{Introduction}

Thermally sprayed ceramic coatings are used to protect engineering components against severe wear and corrosion in a wide range of applications e.g. bearings, aircraft, automotive engines and agricultural machinery [1-6]. Alumina is widely used for its reduced cost, wear resistance, stability at high temperature, good dielectric strength and resistance against chemical attack $[4,7]$. The conventional route for the fabrication of thermally sprayed ceramic coatings involves injecting ceramic powder, in the size range of $\sim 5-100 \mu \mathrm{m}$, into either the plasma arc, in the case of atmospheric plasma spraying (APS), or the oxy-fuel flame in the case of high velocity oxygen fuel (HVOF) thermal spraying. HVOF thermal sprayed alumina has several benefits over APS thermal sprayed alumina coatings e.g. lower porosity and higher wear resistance [8].

Nano-structured, alumina based ceramic coatings have benefits over their conventional counterparts including enhanced adhesive strength ( 65-70 MPa) [9], resistance to crack growth [10,11], and excellent wear performance [12-14]. These coatings have been extensively studied in suspension feedstock studies using a modified HVOF thermal spray setup $[6,9,15-$ 17]. Suspension HVOF (SHVOF) thermal spraying is a variant of HVOF thermal spraying that offers the capability to deposit coatings with fine microstructures from nano to submicron scale liquidised feedstock. In SHVOF thermal spraying, the liquidised feedstock (water or alcohol based) is delivered into the torch combustion chamber $[18,19]$. SHVOF thermal spraying with axial feedstock injection ensures adequate heating of the in-flight powder particles which are then carried to a substrate by a hypersonic gas stream. The deposited coating is built-up from 
layers of splats resulting from the various stages of suspension and flame interaction during SHVOF thermal spraying, namely: the aerodynamic breakup of injected suspension, solvent evaporation and release of particles or agglomerates, and melting of the powder particles [20]. Previous studies have shown that the microstructure of SHVOF coatings are dependent on feedstock characteristics such as particle size distribution, particle morphology, purity and medium of the suspension $[16,21,22]$. Agglomeration of powder particles has also been shown to affect coating microstructure as it modifies the particle-flame interaction during spraying. This is particularly prevalent when spraying suspension made from nano sized powder particles due to their high specific surface area. The size of the agglomerates after the breakupreduction of bulk suspension drops into droplets - also has effect on the type (molten, unmolten or re-solidified) and size of splats in the deposited coating. Thus, thermal mass has an influence on the as-deposited splats since smaller powder particles are likely to melt [22-24]. This will further influence the properties of the coating.

The microstructure of SHVOF alumina coatings have been studied with regards to feedstock composition [24] and processing conditions $[6,9,18]$. The microstructure of SHVOF coatings was shown to be affected by particle size distribution in the suspension and processing parameters which in turn affect the coating density, thickness and the constituent phases. The predominant phase in SHVOF sprayed alumina is typically $\gamma-\mathrm{Al}_{2} \mathrm{O}_{3}$ with some amorphous phase depending on the initial feedstock and/or processing conditions $[6,9,18]$. Coatings with higher phase fractions of $\gamma-\mathrm{Al}_{2} \mathrm{O}_{3}$ are typically homogenous, less porous and have good coating-substrate bonding. Higher phase fraction of $\gamma-\mathrm{Al}_{2} \mathrm{O}_{3}$ is produced by increased heating of the feedstock [6] or the dwell time in the combustion chamber [9]. SHVOF alumina coatings produced from $\alpha-\mathrm{Al}_{2} \mathrm{O}_{3}$ feedstock can also exhibit $\alpha-\mathrm{Al}_{2} \mathrm{O}_{3}$ phase, if the feedstock received reduced heating. Coatings containing $\alpha-\mathrm{Al}_{2} \mathrm{O}_{3}$ typically exhibit a higher porosity [6]. The 
mechanical properties and functional performance of alumina coatings often depend on the coating microstructure [25-27]. The average sliding wear rate of SHVOF thermal sprayed alumina coating containing mostly $\gamma-\mathrm{Al}_{2} \mathrm{O}_{3}$ phase sprayed is in the order of $10^{-6}-10^{-5} \mathrm{~mm}^{3}(\mathrm{Nm})^{-}$ ${ }^{1}[6,9,21]$ whilst coatings containing mostly $\alpha-\mathrm{Al}_{2} \mathrm{O}_{3}$ exhibit sliding wear rates up to two orders of magnitude lower at $10^{-7} \mathrm{~mm}^{3}(\mathrm{Nm})^{-1}$, despite typically having lower porosity [6]. The wear resistance of coatings is known to increase with higher fracture toughness [28]. It is generally accepted that thermal sprayed coatings containing $\alpha-\mathrm{Al}_{2} \mathrm{O}_{3}$ typically have a higher indentation fracture toughness $\left(\sim 1-5.5 \mathrm{MPam}^{0.5}\right)$ as a result of improved wear performance [6]. However, in most cases it is challenging to retain the $\alpha-\mathrm{Al}_{2} \mathrm{O}_{3}$ phase whilst achieving a low porosity content in the coating $(\sim 2-4 \%)[21,24,26]$. Low porosity can be achieved by increasing the temperature or velocity of the in-flight powder particles but this can also induce melting. Melting of the feedstock in thermal sprayed alumina coatings will nucleate $\gamma-\mathrm{Al}_{2} \mathrm{O}_{3}$ from $\alpha$ $\mathrm{Al}_{2} \mathrm{O}_{3}$ melt at the substrate surface $[9,29]$ - as $\gamma-\mathrm{Al}_{2} \mathrm{O}_{3}$ is the most energetically favourable crystalline phase [30]. When depositing thermally sprayed alumina coatings, there exists a trade-off between retaining the more desired $\alpha-\mathrm{Al}_{2} \mathrm{O}_{3}$ phase and reducing porosity in the coating.

Previous studies on thermally sprayed $\mathrm{Al}_{2} \mathrm{O}_{3}$ coatings have typically deposited $\gamma-\mathrm{Al}_{2} \mathrm{O}_{3}$ coatings from thermodynamically stable $\alpha-\mathrm{Al}_{2} \mathrm{O}_{3}$ powder $[6,9,18,25-27]$. Manufacturing thermodynamically stable $\alpha-\mathrm{Al}_{2} \mathrm{O}_{3}$ feedstock powder is achieved through the Bayer's process. Bayer's process is the commercial route for the production of gibbsite $\left[\mathrm{Al}(\mathrm{OH})_{3}\right]$ from bauxite - a mixture of gibbsite and impurities of iron oxides and silicates. The calcination of gibbsite - the last stage of the Bayer's process yields the desired $\alpha-\mathrm{Al}_{2} \mathrm{O}_{3}$ at temperatures above $1000{ }^{\circ} \mathrm{C}$. However, many of the transitional alumina phases can be produced at lower temperatures [31-34]. Producing $\alpha-\mathrm{Al}_{2} \mathrm{O}_{3}$ powder from alumina salts is energy intensive and 
ultimately a wasteful process when thermal spraying of the $\alpha-\mathrm{Al}_{2} \mathrm{O}_{3}$ powder results in the formation of $\gamma-\mathrm{Al}_{2} \mathrm{O}_{3}$. An alternative and more sustainable approach is to use a metastable feedstock such as $\delta-\theta \mathrm{Al}_{2} \mathrm{O}_{3}$ which is easier to obtain and can transform to $\gamma-\mathrm{Al}_{2} \mathrm{O}_{3}$ during thermal spraying. Despite the low cost and availability, there has been little attention given to metastable alumina powder as feedstock for thermal spraying.

The aim of this present work is to investigate the processing of a $\delta-\theta \quad \mathrm{Al}_{2} \mathrm{O}_{3}$ suspension by SHVOF thermal spraying and study its microstructure along with phase changes. The assprayed coating was heat treated and the phase evolution due to the heat treatment was assessed alongside the wear performance of the as-sprayed and heat treated coatings. Microhardness and indentation fracture toughness were also measured to investigate the correlation between microstructure and wear performance of the coatings.

\section{Experimental}

\subsection{Materials and coating fabrication}

Commercially available $\delta-\theta \mathrm{Al}_{2} \mathrm{O}_{3}$ aqueous suspension with a particle loading of $\sim 14$ wt. $\%$ supplied by GTV Verschleißschutz GmbH (Luckenbach, Germany) was used as a feedstock for SHVOF thermal spraying AISI 304 stainless steel $(19.0 \mathrm{Cr}, 9.3 \mathrm{Ni}, 0.05 \mathrm{C}$ and balance Fe in wt.\%) substrates with a dimension of $60 \times 25 \times 2 \mathrm{~mm}$. The suspension was stirred for $1 \mathrm{~h}$ at 700 rpm using a digital overhead stirrer (model IKA RW20 Wilmington, USA) before spraying. All SHVOF coatings were sprayed using a modified UTP TopGun HVOF thermal spray unit from Miller Thermal Inc. (Wisconsin, USA). The suspension was delivered from a pressurized vessel maintained at a pressure of 3 bar with a feed rate of $90 \mathrm{ml} / \mathrm{min}$. All substrates were grit blasted with a blast cleaner from Guyson (Dudley, England) with fine alumina (0.125- 
$0.149 \mathrm{~mm}$ ) particles and 3 bar pressure. The grit blasted substrates were then cleaned in industrial methylated spirit in an ultrasonic bath for $10 \mathrm{~min}$. The substrates were mounted onto a rotating carousel with a vertical axis of rotation of $73 \mathrm{rpm}$ with the spray gun traversing vertically at a speed of $5 \mathrm{mms}^{-1}$ during spraying [6]. The coated substrates were air-cooled during spraying. Detailed spray parameters for the coatings are shown in Table 1. Post-spray heat treatment of the as-sprayed coatings was performed at $600{ }^{\circ} \mathrm{C}$ for $6 \mathrm{~h}$ and $750{ }^{\circ} \mathrm{C}$ for $6 \mathrm{~h}$ and $48 \mathrm{~h}$ at $\sim 15{ }^{\circ} \mathrm{C} \mathrm{min}{ }^{-1}$ heating rate. The coatings were furnace cooled to room temperature at the end of the heat treatment cycle. Heat treatment performed at $600{ }^{\circ} \mathrm{C}$ for $6 \mathrm{~h}, 750{ }^{\circ} \mathrm{C}$ for $6 \mathrm{~h}$, and $750^{\circ} \mathrm{C}$ for $48 \mathrm{~h}$ yielded samples later referred to as $\mathrm{C} 1, \mathrm{C} 2$ and $\mathrm{C} 3$ respectively.

\subsection{Feedstock and coatings characterization}

The $\mathrm{pH}$ of the alumina suspension feedstock was measured with an $\mathrm{S} 400$ benchtop $\mathrm{pH}$ meter from Mettler Toledo (Leicester, UK). The particle size distribution in the suspension was measured with a Malvern Zetasizer Nano-ZS (Malvern, UK). To obtain a sample of dried powder for scanning electron micrograpgh and X-ray diffraction analysis, $200 \mathrm{ml}$ of the suspension was heated in a box furnace at $100{ }^{\circ} \mathrm{C}$ for $8 \mathrm{~h}$.

Micrographs of the coatings and the dried alumina powder were obtained using a scanning electron microscope (SEM) (JEOL 6490, Tokyo Japan) in secondary electron (SE) and in backscattered electron (BSE) modes. The images of the cross sections and the top surface of the coating were obtained using metallographic preparation. Image analysis software Image-J (NIH, USA) was used to measure the porosity of the coatings as the volumetric ratio of pores to solids and the density of surface cracks on the top surface of the $\mathrm{C} 2$ and $\mathrm{C} 3$ coatings. 


\subsection{X-ray diffraction}

$\mathrm{X}$-ray diffraction (XRD) of the coatings (as-sprayed and heat treated) and the powder dried out of the as-received suspension was performed with a Bruker D500 diffractometer (Siemens. A. $\mathrm{B}$, Germany) that uses a $\mathrm{Cu} \mathrm{K} \alpha$ radiation source (1.54 $\AA$ ). The powder was scanned from 10$120^{\circ} 2 \theta$, with a step size of $0.05^{\circ}$ and dwell time of $4 \mathrm{~s}$ while coatings were scanned with 10 to $120^{\circ} 2 \theta$, step of $0.025^{\circ}$ at a dwell of $4 \mathrm{~s}$. A more detailed scan was performed for the coatings to carefully determine phase changes due to heat treatment. Quantitative Rietveld refinement of the XRD data was performed with TOPAS (Coelho Software, Australia) to quantify phases, degree of crystallinity and the crystallite size in the coatings. Structure model of gamma and theta alumina were taken from Zhou and Snyder [35] while for delta alumina Repelin and Husson [36] structure was used. The fundamental parameters profile fitting (FPPF) method [37] was used in the analysis for the crystallite size - only broadening due to coherently scattering domain size modelled by Lorentzian function was considered in the estimation of the crystallite size.

\subsection{Microhardness and indentation fracture toughness}

The microhardness and indentation fracture toughness of the as-sprayed and the heat treated coatings were measured on polished cross-sections at a load of $10 \mathrm{gf}$ and 100 gf respectively using a Vickers microhardness tester (Buehler, USA). Ten microhardness indentations were performed at the centre on the polished cross-section of the coating. The indentation fracture toughness was estimated from five indents with extended radial cracks running parallel to the coating's surface based on Eq. (1) developed by Evans and Charles [38]: 


$$
K_{I C}=0.16(c / a)^{-1.5} H^{0.5} ; c / a \geq 2.5
$$

Equation 1

Where $\mathrm{K}_{\mathrm{IC}}$ is the mode-I fracture toughness in MPa.m ${ }^{0.5}, c$ and $a$ are the crack length and indentation radius respectively while $\mathrm{H}$ is hardness in GPa.

\subsection{Ball-on-flat dry sliding wear}

The as-sprayed and the heat treated coatings polished to $1 \mu \mathrm{m}$ finish were tested for dry sliding wear at room temperature $\left(\sim 25{ }^{\circ} \mathrm{C}\right.$, humidity $\left.\sim 60 \%\right)$ using ball-on-flat reciprocating configuration. $\alpha-\mathrm{Al}_{2} \mathrm{O}_{3}$ balls $(\varnothing 9.5 \mathrm{~mm})$ were used as counterbodies. Testing was performed twice on each coating at a normal contact load of $16.8 \mathrm{~N}$, with a track length of $10 \mathrm{~mm}$ and a sliding speed of $20 \mathrm{~mm} / \mathrm{s}$ for a total sliding distance of $36 \mathrm{~m}$. The wear track was measured with an Alicona Infinite Focus Advanced 3D System (Raaba/Graz, Austria) to give specific wear rate (SWR). Five cross-sectional profiles were taken at different locations along the wear track length to obtain the effective area of material loss, which were then multiplied by the track length to calculate volumetric material loss. The specific wear rate was thus the ratio of the volumetric material loss to the product of total sliding distance and normal contact load. The wear of the $\alpha-\mathrm{Al}_{2} \mathrm{O}_{3}$ ball was estimated on the assumption that the flattened wear scar, covering the contact points on its face, depicts a spherical crest. The volumetric material loss of the counter body was thus estimated from equations described by Tippaban in [39]. Coating wear track morphology was examined using scanning electron microscopy and the scar on the $\alpha-\mathrm{Al}_{2} \mathrm{O}_{3}$ counter body was examined with an optical microscope (Nikon Eclipse LV100NDTokyo, Japan). 


\section{Results}

\subsection{Feedstock suspension}

The $\mathrm{Al}_{2} \mathrm{O}_{3}$ suspension had a $\mathrm{pH}$ of $\sim 4.6$. The powder particles in the suspension, as shown in Fig. 1, were agglomerates of irregular powder morphology. The particle size distribution of the suspension is shown in Fig. 2 and appears to be a mono-modal distribution with a median size $\left(\mathrm{D}_{50}\right)$ of $\sim 137 \mathrm{~nm}$. The particles had a $\mathrm{D}_{10}$ of $\sim 83 \mathrm{~nm}$ and $\mathrm{D}_{90}$ of $\sim 225 \mathrm{~nm}$ respectively. The sharpness index is defined as the ratio of $\mathrm{D}_{10} / \mathrm{D}_{50}$ for the fine fraction and $\mathrm{D}_{50} / \mathrm{D}_{90}$ for the coarse fraction [40]. The sharpness index obtained for both the fine and coarse fraction is $\sim 0.6$ for the particles in the suspension; thus, the suspension has equal proportions of fine and coarse aggregates. The XRD profile of the as-received powder (Fig. 3) shows metastable phase composition, which consists of delta (tetragonal) and theta (monoclinic) alumina [41].

\subsection{Coating Microstructure}

\subsubsection{As-sprayed coating}

A BSE cross-sectional image of the as-sprayed $\mathrm{Al}_{2} \mathrm{O}_{3}$ coating is shown in Fig. 4. The coating shows good bonding to the substrate as determined by the absence of cracks or delamination at the coating-substrate interface. The thickness of the coating is $\sim 40 \pm 2 \mu \mathrm{m}$ corresponding to $\sim 5 \pm 0.3 \mu \mathrm{m}$ per spray pass. The porosity in the as-sprayed coating is $7.3 \% \pm 0.4$, as identified by the darker contrast regions seen in Fig. 6 . The pores are unevenly scattered across the cross-section and are of varying morphology. The SE image of the top surface of the assprayed coating at low magnification (Fig. 5a) shows no visible cracks. 


\subsubsection{Heat treated coatings}

The SE top surface images of the coatings heat treated at $600{ }^{\circ} \mathrm{C}$ for $6 \mathrm{~h}$ (labelled as $\mathrm{C} 1$ ) and at $750{ }^{\circ} \mathrm{C}$ for $6 \mathrm{~h}$ (labelled as $\mathrm{C} 2$ ) are shown in Fig. 5(b) and (c) respectively. The $\mathrm{C} 1$ coating has similar surface features to the as-sprayed coatings. The $\mathrm{C} 2$ coating however, exhibited a range of cracks. These cracks were observable regardless of the heat treatment time, as shown in Fig. 5 (c) and (d). The observed cracks divided the coating surface into web-like fragments. The coating heat treated at $750^{\circ} \mathrm{C}$ for $48 \mathrm{~h}$ (labelled as C3) has an estimated 22 fragments per $\mathrm{mm}^{2}$ while the $\mathrm{C} 2$ coating has 25 fragments per $\mathrm{mm}^{2}$. The $\mathrm{C} 1$ coating has a porosity of $5.4 \% \pm 0.4$ while the $\mathrm{C} 2$ and $\mathrm{C} 3$ have a porosity of $6.4 \% \pm 0.5$ and of $5.7 \% \pm 0.5$ respectively.

\subsection{X-ray diffraction}

Combined XRD profiles of the as-prayed and heat treated coatings (C1, C2 and C3) are shown in Fig. 7(a). There is a significant amorphous content in the as-sprayed coating which shows as a broad hump at $32^{\circ}$ and $62^{\circ} 2 \theta$. Its degree of crystallinity is $\sim 20 \%$ and predominantly comprises of cubic $\gamma-\mathrm{Al}_{2} \mathrm{O}_{3}$. The amorphous and $\gamma-\mathrm{Al}_{2} \mathrm{O}_{3}$ phases were mostly retained in the $\mathrm{C} 1$ coating where as for the $\mathrm{C} 2$ and the $\mathrm{C} 3$ coatings, the $\gamma-\mathrm{Al}_{2} \mathrm{O}_{3}$ and amorphous phases mostly transformed to tetragonal $\delta-\mathrm{Al}_{2} \mathrm{O}_{3}$ with trace amounts of $\theta-\mathrm{Al}_{2} \mathrm{O}_{3}$. However, there was obvious peak broadening across the XRD profiles of the $\mathrm{C} 2$ and $\mathrm{C} 3$ coatings.

The $\gamma-\mathrm{Al}_{2} \mathrm{O}_{3}$ crystallite size in the as-sprayed coating was $31.8 \mathrm{~nm}$. There is a slight growth to $33.5 \mathrm{~nm}$ in the $\mathrm{C} 1$ coating but a significant size refinement to $17.5 \mathrm{~nm}$ in the $\mathrm{C} 2$ coating and $17.7 \mathrm{~nm}$ in the $\mathrm{C} 3$ coating. In addition, the crystallite size of the delta alumina phases was 10.9 $\mathrm{nm}$ in the $\mathrm{C} 2$ coating and $11.1 \mathrm{~nm}$ in the $\mathrm{C} 3$ coating. Overall, there was a reduction in crystallite 
size for both coatings heat treated at $750{ }^{\circ} \mathrm{C}$. Reflections of $\alpha$ and $\gamma$-iron found in the XRD patterns are from the substrates while the calcite is a sample mounting artefact.

\subsection{Microhardness and indentation fracture toughness}

Fig. 8 shows the mean microhardness and associated standard error of the as-sprayed and heat treated coatings. The as-sprayed coating had a mean microhardness of $9 \pm 1 \mathrm{GPa}$, which falls in the reported range of 6-9 GPa for SHVOF thermally sprayed alumina coatings [19]. The microhardness of the $\mathrm{C} 1$ coating was $12 \pm 2 \mathrm{GPa}$, which is an improvement of $30 \%$ over the as-sprayed coating. A further increase was seen for the $\mathrm{C} 2$ and the $\mathrm{C} 3$ coatings with microhardness values of $14 \pm 3 \mathrm{GPa}$ and $16 \pm 3 \mathrm{GPa}$ respectively.

The fracture toughness $\left(\mathrm{K}_{\mathrm{IC}}\right)$ of the as-sprayed and heat treated coatings is shown in Fig. 9 (a). The as-sprayed and $\mathrm{C} 1$ coating have the lowest $\mathrm{K}_{\mathrm{IC}}$ with values of $\sim 0.8 \pm 0.1 \mathrm{MPam}^{0.5}$ and 0.7 \pm 0.1 respectively while the $\mathrm{C} 2$ and $\mathrm{C} 3$ coatings have values of $\sim 1.2 \pm 0.2 \mathrm{MPam}^{0.5}$ and $1.7 \pm$ $0.5 \mathrm{MPam}^{0.5}$ respectively. The normalised crack extension plot [38] in Fig. 9 (b) shows c/a values which indicate the compliance of the obtained values calculated with the Evans and Charles model. It shows the tendency of $\mathrm{c} / \mathrm{a}$ to increase as $\mathrm{K}_{\mathrm{IC}} / 0.16 \mathrm{Ha}^{0.5}$ decreases. The corresponding c/a value to an estimated $\mathrm{K}_{\mathrm{IC}}$ should be $\geq 2.5$ to fit the model. The compliance of the values obtained for the $\mathrm{C} 3$ coating are reduced if its c/a range is considered.

\subsection{Dry sliding wear}

Fig. 10 and 11 show the specific wear rate of the coatings and the counter body respectively. The sliding wear test results showed good repeatability, considering the data in SWR-1 (test 1) and SWR-2 (test 2). All coatings exhibit specific wear rate below $10^{-6} \mathrm{~mm}^{3}(\mathrm{Nm})^{-1}$ (Fig. 10). 
The as-sprayed and the $\mathrm{C} 1$ coating showed a similar order of specific wear rate after a sliding distance of $36 \mathrm{~m}$. This performance is about one order of magnitude lower than what was measured in the $\mathrm{C} 2$ coating that only lasted for a sliding distance of $\sim 4 \mathrm{~m}$. The $\mathrm{C} 2$ and the $\mathrm{C} 3$ coatings differ by up to one order of magnitude, although the latter only lasted for a sliding distance of $\sim 1 \mathrm{~m}$ after which it showed severe wear behaviour. The counter body only experienced measurable wear against the as-sprayed and the $\mathrm{C} 1$ coatings and the specific wear rates on the $\alpha-\mathrm{Al}_{2} \mathrm{O}_{3}$ balls was a little more than one order of magnitude higher than the specific wear rate seen on the coatings. The counter-body on the $\mathrm{C} 2$ and the $\mathrm{C} 3$ coatings did not show any measurable wear.

The SEM micrographs of the wear tracks on the coatings and the optical images of counter body contact areas for as-sprayed and the $\mathrm{C} 1$ coating are shown in Fig. 12 and the images of $\mathrm{C} 2$ and the $\mathrm{C} 3$ coatings are shown in Fig. 13. The as-sprayed and the $\mathrm{C} 1$ coating show finegrooved tracks marked by the arrows with additional tribofilm features (Fig. 12 (a) and (b)) similar to a type II tribofilm described by Yang et al. [42]. As shown on the C1 coating wear track, this type of tribofilm is expected to consist of fine grains of similar size. Corresponding wear scars with no material transfer were also seen on the counter body in contact with each of the coatings (Fig. 12 (c) and (d)). In contrast, the wear tracks of the C2 and the C3 coatings presented in Fig. 13 (a) and (b) are covered by wear debris due to material transfer from the coatings which has been crunched and then piled together. The counter-body thus shows evidence of material transfer from the coatings (Fig. 13 (c) and (d)). 


\section{Discussion}

The discussion section is separated into two parts-the first part explains the coating microstructure and phase evolution while the second part explains the wear performance of the coatings.

\subsection{Microstructure and evolution of phases}

The homogenous microstructure of the as-sprayed coating was built from splats of varying sizes and geometries which formed from molten agglomerates of different sizes. The suspension feedstock was made up of equivalent proportion of fines and coarse aggregates, as indicated by the sharpness index (see Section 3.1), which resulted in a coating with porosity level of 5-7\%. This level of porosity is typical of coatings developed from nano and micro sized feedstock $[21,24]$. The cross-section of the as-sprayed coating shows an uneven mix of bright and dark phases, which has also been observed by Murray et al. [6] in SHVOF thermal spraying of alpha alumina feedstock. What the bright and dark phases represents in alumina coatings is subject to further investigation.

Coating microstructures built from rapidly quenched molten agglomerates of alumina particles typically consist of amorphous and/or cubic $\gamma-\mathrm{Al}_{2} \mathrm{O}_{3}[5,6,9,29,43]$. This is because $\gamma-\mathrm{Al}_{2} \mathrm{O}_{3}$ is the most energetically favourable crystalline phase during solidification of alumina melt [30]. $\gamma-\mathrm{Al}_{2} \mathrm{O}_{3}$ is energetically favourable as the formation of alumina phases is governed by the Ostwald rule of successive formation $[44,45]$, which states that the least stable reaction product precipitates first [46]. $\gamma-\mathrm{Al}_{2} \mathrm{O}_{3}$ precipitates before other phases of alumina from the melt as the least stable phase of alumina based on the Ostwald rule. Its formation from the melt is a positive 
entropy change reaction [47] and it is the closest phase to the highly disordered molten alumina. Amorphous alumina can also be formed during solidification of alumina melt instead of the $\gamma-$ $\mathrm{Al}_{2} \mathrm{O}_{3}$ when long range order is lost [48].

The favourable formation of $\gamma-\mathrm{Al}_{2} \mathrm{O}_{3}$ can be understood by considering the coordination of the alumina phases. Rhombohedral $\alpha-\mathrm{Al}_{2} \mathrm{O}_{3}$ has only octahedral coordination whereas cubic $\gamma$ $\mathrm{Al}_{2} \mathrm{O}_{3}$ has both octahedral and tetrahedral coordination [49]. This has been attributed to its higher entropy state compared to the $\alpha-\mathrm{Al}_{2} \mathrm{O}_{3}$ phase [47]. The phase formation in alumina can be further understood by considering both the thermodynamics of the formation and the mechanism of the formation [50]. At temperature just above the melting point, ions have lower coordination number and for alumina melt, the prevalence of oxygen with four times the coordination number of aluminium is most likely [51]. However, alpha alumina requires twothird of its octahedral sites to be filled by $\mathrm{Al}^{3+}$ [49] but this often is not the case because of the rapid quenching in thermal spray. As such, the structures with tetrahedral coordination form more readily than structures with only octahedral coordination. This explains the amorphous hump and $\gamma-\mathrm{Al}_{2} \mathrm{O}_{3} \quad[9,22,52]$ observed in the X-ray diffraction pattern of the as-sprayed coatings.

Post spray heat treatment of as-sprayed coatings typically results in phase transformation and increased microhardness [53]. Phase transformation from $\gamma-\mathrm{Al}_{2} \mathrm{O}_{3}$ to $\delta-\mathrm{Al}_{2} \mathrm{O}_{3}$ was observed for the coatings after the heat treatment. $\delta-\mathrm{Al}_{2} \mathrm{O}_{3}$ is a superstructure of $\gamma-\mathrm{Al}_{2} \mathrm{O}_{3}$ with tripled c-axis due to ordering of cationic vacancies on the octahedral site as governed by a screw tetrad parallel to the c-direction [54]. The observed phase transformation $\left(\gamma-\mathrm{Al}_{2} \mathrm{O}_{3}\right.$ to $\left.\delta-\mathrm{Al}_{2} \mathrm{O}_{3}\right)$ can be attributed to stacking of the cubic crystals that resulted into the tetragonal structure as shown in Fig. 7 (b). 
The x-ray diffraction pattern of the heat treated coatings showed peak broadening (see Section 3.3). Peak broadening in x-ray diffraction is a measure of crystal imperfections and it can occur due to one or all of the following: dislocation density, stacking faults, twinning, micro-stress, grain boundaries, and chemical heterogeneities and reduced crystallite size [55,56]. Due to the post-spray heat treatment of the coatings, the broadened peaks can be reliably attributed to crystallite size reduction, though there is a possible contribution from stacking faults, due to the process of piling of the cubic crystals of the $\gamma-\mathrm{Al}_{2} \mathrm{O}_{3}$ to form the tetragonal crystals of the $\delta-\mathrm{Al}_{2} \mathrm{O}_{3}$. The transformations described so far are consistent with reported phase transitions in bulk $\mathrm{Al}_{2} \mathrm{O}_{3}$ [41] and post-spray heat treated $\mathrm{Al}_{2} \mathrm{O}_{3}$ coatings [9].

The phase transformations discussed so far were accompanied by refined crystallite size in the heat treated coatings. This could have contributed to the improved microhardness of the heat treated coatings as explained by the Hall-Petch effect, which describes how the microhardness of non-work hardened bulk material can increase with a reduction in grain size $[57,58]$. The microhardness values of the coatings were nonetheless below those reported by Murray et al. [6] for $\mathrm{Al}_{2} \mathrm{O}_{3}$ coatings sprayed with the same UTP TopGun. However, in that case a $\alpha-\mathrm{Al}_{2} \mathrm{O}_{3}$ feedstock was used and so a direct comparison cannot be made.

Sintering, possibly due to consolidation of splats, was observed in the heat treated coatings. Sintering is known to produce a bridging effect, coalescence between adjacent splats, that can initiate localized crack resistance [59]. This could possibly explain the increased fracture toughness observed for the heat treated alumina coatings. However, the fracture toughness results are inconclusive and will require further investigation.

The small decrease in the porosity of the heat treated coatings compared to the as-sprayed coating can also be attributed to splat consolidation. The mechanisms promoting sintering 
during heat treatment include, but are not limited to, lattice diffusion via interstitials and lattice diffusion via vacancies. In this work, the latter is most applicable as the observed phase transformation appeared to be through vacancy ordering. $\delta-\mathrm{Al}_{2} \mathrm{O}_{3}$, as a superstructure of $\gamma$ $\mathrm{Al}_{2} \mathrm{O}_{3}$, was formed from the ordering of the vacant octahedral sites on the $\gamma-\mathrm{Al}_{2} \mathrm{O}_{3}$ cubic crystal through stacking [54]. The grain growth stage of the sintering process could have facilitated the fusion of adjacent cubic crystals of $\gamma-\mathrm{Al}_{2} \mathrm{O}_{3}$ that then grew in size to attain the tetragonal crystal structure of the $\delta-\mathrm{Al}_{2} \mathrm{O}_{3}$ [60]. As the grain growth then progresses, the interfacial energy balance is broken to allow pore elimination and coalescence [61]. Twinning may have resulted from this process which then contributed to the observed peak broadening.

\subsection{Tribology and wear behaviour}

The specific wear rate recorded from the dry sliding wear tests of the as-sprayed and the $\mathrm{C} 1$ coatings was of the order of $\sim 10^{-8} \mathrm{~mm}^{3}(\mathrm{Nm})^{-1}$. Both coatings show adhesive wear in the mild wear regime as evident from the fine-grooved track (Fig. 12 (a) and (b)) resulting from the plastic deformation undergone by the coating. There was no obvious case of pull-out, but the fine grooves could be from very fine debris generated that smeared on the coating surface due to high stress between the sliding bodies [21]. The size of the scar left on the counter-body by both coatings (Fig. 12 (c) and (d)) also suggest similarity in their wear mechanisms - the SWR is $3.56 \times 10^{-7} \mathrm{~mm}^{3}(\mathrm{Nm})^{-1}$ on the as-sprayed coating and $2.56 \times 10^{-7} \mathrm{~mm}^{3}(\mathrm{Nm})^{-1}$ on the $\mathrm{C} 1$ coating. This is further reinforced by the fact that both coatings have similar microstructures, microhardness and indentation fracture toughness. Despite the higher microhardness and indentation fracture toughness of the coatings heat treated at $750{ }^{\circ} \mathrm{C}$ (see section 3.4 ), the coating integrity appears to have been compromised by the surface fragmentation and as a result the coating suffered severe wear. Alumina coatings under dry sliding condition show three stages of wear: the first stage involves increasing wear rate, the second stage shows 
steady wear rate, and the third stage usually shows rapid material removal until eventual wearing out of the coating layer [62]. Each stage is dominated by different mechanisms: the first is dominated by adhesion, the second stage by polishing and abrasive wear which leads to increased material removal on the third stage [63]. The severe wear is likely to be initiated by wear debris trapped in between the sliding bodies thereby causing 3-body abrasive wear resulting in further material removal [64]. This explains the poor wear performance observed in the $\mathrm{C} 2$ and the $\mathrm{C} 3$ coatings - interestingly, it suggests the possibility of an optimum heat treatment temperature of $600{ }^{\circ} \mathrm{C}$ in $\mathrm{Al}_{2} \mathrm{O}_{3}$ on stainless steel applications.

\section{Conclusions}

In this study, a delta-theta alumina suspension was deposited onto a stainless-steel substrate using SHVOF thermal spraying. The as-sprayed and post-sprayed heat treated coatings were studied for phase evolution and wear performance and the following conclusions can be drawn:

- The microstructure of the as-sprayed coating from a delta-theta alumina suspension is consistent with those from the conventional $\alpha-\mathrm{Al}_{2} \mathrm{O}_{3}$ feedstock showing fully molten splats with the characteristics of amorphous and $\gamma-\mathrm{Al}_{2} \mathrm{O}_{3}$.

- The $\gamma-\mathrm{Al}_{2} \mathrm{O}_{3}$ (cubic) phase in the coating partially transformed to become $\delta-\mathrm{Al}_{2} \mathrm{O}_{3}$ (tetragonal) at a heat treatment temperature of $750{ }^{\circ} \mathrm{C}$. The transformation likely occurred through vacancy ordering accompanied with crystallite size refinement. This resulted in peak broadening within the XRD profiles of the heat treated coatings.

- The microhardness and the fracture toughness of the as-sprayed coating and the coating heat treated at $600{ }^{\circ} \mathrm{C}$ were similar. The microhardness and the fracture toughness of the coatings heat treated at $750{ }^{\circ} \mathrm{C}$ increased by an approximate factor of two. This was 
attributed to grain refinement, pore consolidation and phase transformation from amorphous and cubic $\gamma-\mathrm{Al}_{2} \mathrm{O}_{3}$ alumina to tetragonal delta alumina.

- The wear rate of the as-sprayed coating was $5.53 \times 10^{-9} \mathrm{~mm}^{3}(\mathrm{Nm})^{-1}$ and $2.94 \times 10^{-9}$ $\mathrm{mm}^{3}(\mathrm{Nm})^{-1}$ for the coating heat treated at $600{ }^{\circ} \mathrm{C}$, which seems to be an optimum heat treatment temperature for alumina on stainless-steel substrates. In both cases, the integrity of the coating was retained as no surface defects developed due to heat treatment. This enabled the wear of the coating to not progress beyond the mild regime. The coatings heat treated at $750{ }^{\circ} \mathrm{C}$ for both $6 \mathrm{~h}$ and $48 \mathrm{~h}$ both failed abruptly by severe wear due to pre-cracked surfaces.

\section{Acknowledgements}

The authors acknowledge the experimental support offered by Mr R. Screaton in spraying the coating samples, Dr B. Mingwen helped in the phase analysis of the coating samples. Dr J. Daure and Dr W. Syam helped in completing the wear tests and wear track analysis. The authors are grateful to Dr George Jackson for proof reading the manuscript. The authors thank the Nanoscale and Microscale Research Centre (nmRC) for providing access to instrumentation. Tunji Owoseni is supported by Petroleum Technology Development Fund (PTDF), Nigeria under the overseas scholarship scheme.

\section{References}

[1] J. Kotlan, R.C. Seshadri, S. Sampath, P. Ctibor, Z. Pala, R. Musalek, On the dielectric strengths of atmospheric plasma sprayed $\mathrm{A} 12 \mathrm{O} 3, \mathrm{Y} 2 \mathrm{O} 3, \mathrm{ZrO} 2-7 \% \mathrm{Y} 2 \mathrm{O} 3$ and (Ba,Sr)TiO3 coatings, Ceram. Int. 41 (2015) 11169-11176.

[2] J. Rong, K. Yang, H. Zhao, C. Liu, Y. Zhuang, S. Tao, Tribological performance of 
plasma sprayed Al2O3-Y2O3 composite coatings, Surf. Coatings Technol. 302 (2016) $487-494$.

[3] B. Bernard, A. Quet, L. Bianchi, A. Joulia, A. Malié, V. Schick, B. Rémy, Thermal insulation properties of YSZ coatings: Suspension Plasma Spraying (SPS) versus Electron Beam Physical Vapor Deposition (EB-PVD) and Atmospheric Plasma Spraying (APS), Surf. Coatings Technol. 318 (2017) 122-128.

[4] M. Herrmann, F.L. Toma, L.M. Berger, G. Kaiser, C.C. Stahr, Comparative study of the corrosion resistance of thermally sprayed ceramic coatings and their bulk ceramic counterparts, J. Eur. Ceram. Soc. 34 (2014) 493-504.

[5] J.W. Murray, G.A. Rance, F. Xu, T. Hussain, Alumina-graphene nanocomposite coatings fabricated by suspension high velocity oxy-fuel thermal spraying for ultra-lowwear, J. Eur. Ceram. Soc. 38 (2018) 1819-1828.

[6] J.W. Murray, A.S.M. Ang, Z. Pala, E.C. Shaw, T. Hussain, Suspension High Velocity Oxy-Fuel (SHVOF)-Sprayed Alumina Coatings: Microstructure, Nanoindentation and Wear, J. Therm. Spray Technol. 25 (2016) 1700-1710.

[7] J.R. Davis, Handbook of Thermal Spray Technology, ASM International, Ohio, 2004.

[8] G. Bolelli, L. Lusvarghi, T. Manfredini, F.P. Mantini, R. Polini, E. Turunen, T. Varis, S.-P. Hannula, Comparison between plasma- and HVOF-sprayed ceramic coatings. Part I: microstructure and mechanical properties, Int. J. Surf. Sci. Eng. 1 (2007) 38-61.

[9] G. Bolelli, V. Cannillo, R. Gadow, A. Killinger, L. Lusvarghi, T. Manfredini, P. Müller, Properties of A12O3 coatings by High Velocity Suspension Flame Spraying (HVSFS): Effects of injection systems and torch design, Surf. Coatings Technol. 270 (2015) 175189.

[10] E.. Jordan, M. Gell, Y.. Sohn, D. Goberman, L. Shaw, S. Jiang, M. Wang, T.. Xiao, Y. Wang, P. Strutt, Fabrication and evaluation of plasma sprayed nanostructured alumina- 
titania coatings with superior properties, Mater. Sci. Eng. A. 301 (2001) 80-89.

[11] N.H. Faisal, R. Ahmed, A.K. Prathuru, S. Spence, M. Hossain, J.A. Steel, An improved Vickers indentation fracture toughness model to assess the quality of thermally sprayed coatings, Eng. Fract. Mech. 128 (2014) 189-204.

[12] M. Gell, E.H. Jordan, Y.H. Sohn, D. Goberman, L. Shaw, T.D. Xiao, Development and implementation of plasma sprayed nanostructured ceramic coatings, Surf. Coatings Technol. 146-147 (2001) 48-54.

[13] W. Żórawski, A. Góral, O. Bokuvka, L. Lityńska-Dobrzyńska, K. Berent, Microstructure and tribological properties of nanostructured and conventional plasma sprayed alumina-titania coatings, Surf. Coatings Technol. 268 (2015) 190-197.

[14] A. Rico, P. Poza, J. Rodríguez, High temperature tribological behavior of nanostructured and conventional plasma sprayed alumina-titania coatings, Vacuum. 88 (2013) 149-154.

[15] P. Muller, A. Killinger, R. Gadow, Comparison between high-velocity suspension flame spraying and suspension plasma spraying of alumina, J. Therm. Spray Technol. 21 (2012) 1120-1127.

[16] M. Bai, H. Maher, Z. Pala, T. Hussain, Microstructure and phase stability of suspension high velocity oxy-fuel sprayed yttria stabilised zirconia coatings from aqueous and ethanol based suspensions, J. Eur. Ceram. Soc. (2017).

[17] Z. Pala, E. Shaw, J.W. Murray, N. Senin, T. Hussain, Suspension high velocity oxy-fuel spraying of TiO2: a quantitative approach to phase composition, J. Eur. Ceram. Soc. (2016).

[18] A. Killinger, M. Kuhn, R. Gadow, High-Velocity Suspension Flame Spraying (HVSFS), a new approach for spraying nanoparticles with hypersonic speed, Surf. Coatings Technol. 201 (2006) 1922-1929.

[19] R. Gadow, A. Killinger, J. Rauch, Introduction to high-velocity suspension flame 
spraying (HVSFS), J. Therm. Spray Technol. 17 (2008) 655-661.

[20] C. Delbos, J. Fazilleau, V. Rat, J.F. Coudert, P. Fauchais, B. Pateyron, Phenomena Involved in Suspension Plasma Spraying Part 2: Zirconia Particle Treatment and Coating Formation, Plasma Chem. Plasma Process. 26 (2006) 393-414.

[21] G. Bolelli, B. Bonferroni, V. Cannillo, R. Gadow, A. Killinger, L. Lusvarghi, J. Rauch, N. Stiegler, Wear behaviour of high velocity suspension flame sprayed (HVSFS) Al2O3 coatings produced using micron- and nano-sized powder suspensions, Surf. Coatings Technol. 204 (2010) 2657-2668.

[22] L. Pawlowski, Suspension and solution thermal spray coatings, Surf. Coatings Technol. 203 (2009) 2807-2829.

[23] R. Moreno, E. Bannier, Feedstock suspensions and solutions, in: Futur. Dev. Therm. Spray Coatings Types, Des. Manuf. Appl., Elsevier Ltd., 2015: pp. 51-80.

[24] G. Bolelli, V. Cannillo, R. Gadow, A. Killinger, L. Lusvarghi, J. Rauch, M. Romagnoli, Effect of the suspension composition on the microstructural properties of high velocity suspension flame sprayed (HVSFS) Al2O3 coatings, Surf. Coatings Technol. 204 (2010) 1163-1179.

[25] J. Rauch, G. Bolelli, A. Killinger, R. Gadow, V. Cannillo, L. Lusvarghi, Advances in High Velocity Suspension Flame Spraying (HVSFS), Surf. Coatings Technol. 203 (2009) 2131-2138.

[26] G. Bolelli, J. Rauch, V. Cannillo, A. Killinger, L. Lusvarghi, R. Gadow, Microstructural and tribological investigation of high-velocity suspension flame sprayed (HVSFS) Al $2 \mathrm{O} 3$ coatings, J. Therm. Spray Technol. 18 (2009) 35-49.

[27] F.L. Toma, L.M. Berger, S. Scheitz, S. Langner, C. Rödel, A. Potthoff, V. Sauchuk, M. Kusnezoff, Comparison of the microstructural characteristics and electrical properties of thermally sprayed $\mathrm{Al} 2 \mathrm{O} 3$ coatings from aqueous suspensions and feedstock 
powders, J. Therm. Spray Technol. 21 (2012) 480-488.

[28] R. Singha Roy, A. Mondal, A. Chanda, D. Basu, M.K. Mitra, Sliding wear behavior of submicron-grained alumina in biological environment., J. Biomed. Mater. Res. A. 83 (2007) 257-62.

[29] J.W. Murray, A. Leva, S. Joshi, T. Hussain, Microstructure and wear behaviour of powder and suspension hybrid Al2O3-YSZ coatings, Ceram. Int. (2018).

[30] R. McPherson, On the formation of thermally sprayed alumina coatings, J. Mater. Sci. 15 (1980) 3141-3149.

[31] I. Levin, L.A. Bendersky, D.G. Brandon, M. Rühle, Cubic to monoclinic phase transformations in alumina, Acta Mater. 45 (1997) 3659-3669.

[32] I. Levin, D. Brandon, Metastable Alumina Polymorphs: Crystal Structures and Transition Sequences, J. Am. Ceram. Soc. 81 (2005) 1995-2012.

[33] M. Uma Devi, New phase formation in Al2O3-based thermal spray coatings, Ceram. Int. 30 (2004) 555-565.

[34] M. Uma Devi, On the nature of phases in Al2O3 and Al2O3-SiC thermal spray coatings, Ceram. Int. 30 (2004) 545-553.

[35] R. -S Zhou, R.L. Snyder, Structures and transformation mechanisms of the $\eta, \gamma$ and $\theta$ transition aluminas, Acta Crystallogr. Sect. B. 47 (1991) 617-630.

[36] Y. Repelin, E. Husson, Etudes structurales d'alumines de transition. I-alumines gamma et delta, Mater. Res. Bull. 25 (1990) 611-621.

[37] R.W. Cheary, A.A. Coelho, J.P. Cline, Fundamental parameters line profile fitting in laboratory diffractometers, J. Res. Natl. Inst. Stand. Technol. 109 (2004) 1.

[38] A.G. Evans, E.A. Charles, Fracture toughness determination by indentation, J. Am. Ceram. Soc. 59 (1976) 371-372.

[39] P.H. Shipway, The role of test conditions on the microabrasive wear behaviour of soda- 
lime glass, in: Wear, 1999: pp. 191-199.

[40] Don McGlinchey, Henk G. Merkus and Gabriel M.H. Meesters “ Production, Handling and Characterization of Particulate Materials " Springer International Publishing (Switzerland, 2016), pg. 528, in: G.H. Merkus, M.H.G. Meesters (Eds.), Prod. Handl. Charact. Part. Mater., 2016: p. 528.

[41] G. Busca, The surface of transitional aluminas: A critical review, Catal. Today. 226 (2014) 2-13.

[42] Q. Yang, T. Senda, N. Kotani, A. Hirose, Sliding wear behavior and tribofilm formation of ceramics at high temperatures, Surf. Coatings Technol. 184 (2004) 270-277.

[43] G. Di Girolamo, A. Brentari, C. Blasi, E. Serra, Microstructure and mechanical properties of plasma sprayed alumina-based coatings, Ceram. Int. 40 (2014) 1286112867.

[44] R.. Damani, P. Makroczy, Heat treatment induced phase and microstructural development in bulk plasma sprayed alumina, J. Eur. Ceram. Soc. 20 (2000) 867-888.

[45] R. McPherson, Formation of metastable phases in flame- and plasma-prepared alumina.pdf, J. Mater. Sci. 8 (1973) 851-858.

[46] R.A. Van Santen, The Ostwald step rule, J. Phys. Chem. 88 (1984) 5768-5769.

[47] J.M. Mchale, A. Auroux, A.J. Perrotta, A. Navrotsky, Surface Energies and Thermodynamic Phase Surface Energies and Thermodynamic Phase Stability in Nanocrystalline Aluminas, 788 (2010) 788-792.

[48] J. Metson, Production of alumina, Woodhead Publishing Limited, 2010.

[49] A. Boumaza, L. Favaro, J. Lédion, G. Sattonnay, J.B. Brubach, P. Berthet, A.M. Huntz, P. Roy, R. Tétot, Transition alumina phases induced by heat treatment of boehmite: An X-ray diffraction and infrared spectroscopy study, J. Solid State Chem. 182 (2009) 1171-1176. 
[50] M. Plummer, The formation of metastable aluminas at high temperatures, J. Appl. Chem. 8 (2007) 35-44.

[51] H.P. Rooksby, The Formation and Structure of Delta Alumina, Clay Miner. 4 (1961) 234-238.

[52] A. Killinger, P. M??ller, R. Gadow, What Do We Know, What are the Current Limitations of Suspension HVOF Spraying?, J. Therm. Spray Technol. 24 (2015) 11301142.

[53] J. Rong, K. Yang, Y. Zhuang, J. Ni, H. Zhao, S. Tao, X. Zhong, C. Ding, Phase and Microstructure Evolution and Toughening Mechanism of a Hierarchical Architectured A12O3-Y2O3 Coating under High Temperature, J. Therm. Spray Technol. 27 (2018) $358-370$.

[54] Y.G. Wang, P.M. Bronsveld, J.T.M. DeHosson, B. Djuričić, D. McGarry, S. Pickering, Ordering of Octahedral Vacancies in Transition Aluminas, J. Am. Ceram. Soc. 81 (2005) $1655-1660$.

[55] A. Khorsand Zak, W.H. Abd. Majid, M.E. Abrishami, R. Yousefi, X-ray analysis of ZnO nanoparticles by Williamson-Hall and size-strain plot methods, Solid State Sci. 13 (2011) 251-256.

[56] T. Ungár, Microstructural parameters from X-ray diffraction peak broadening, Scr. Mater. 51 (2004) 777-781.

[57] E.O. Hall, Variation of Hardness of Metals with Grain Size, Nature. 173 (1954) 948949.

[58] A.S. Taha, F.H. Hammad, Application of the Hall-Petch Relation to Microhardness Measurements on Al, Cu, Al-MD 105, and Al-Cu Alloys, Phys. Status Solidi. 119 (1990) $455-462$.

[59] P. Chantikul, S.J. Bennison, B.R. Lawn, Role of Grain Size in the Strength and R-Curve 
Properties of Alumina, J. Am. Ceram. Soc. 73 (1990) 2419-2427.

[60] F. Thümmler, W. Thomma, The sintering process, Metall. Rev. 12 (1967).

[61] Z.Z. Fang, H. Wang, X. Wang, V. Kumar, Grain growth during sintering of nanosized particles, Ceram. Trans. 209 (2010) 389-400.

[62] D.. Pantelis, P. Psyllaki, N. Alexopoulos, Tribological behaviour of plasma-sprayed Al2O3 coatings under severe wear conditions, Wear. 237 (2000) 197-204.

[63] V.P. Singh, A. Sil, R. Jayaganthan, A study on sliding and erosive wear behaviour of atmospheric plasma sprayed conventional and nanostructured alumina coatings, Mater. Des. 32 (2011) 584-591.

[64] B. Bhushan, Introduction to Tribology, John Wiley \& Sons, Ltd, The Atrium, Southern Gate, Chichester, West Sussex, PO19 8SQ, UK, 2013. 